\title{
14
}

\section{CAREFUL REARRANGEMENTS}

\section{Experiments with Neglected 'Things' in Architecture}

\author{
Micol Rispoli
}

\section{Introduction}

In the last years care has increasingly been used by designers as a politically and morally charged term to engage with emerging issues of social and environmental concern, as shown by the growing number of initiatives revolving around it, such as exhibitions and festivals. ${ }^{1}$ As a concept specifically originated in feminist theory to highlight our constitutive vulnerability and interdependency (Federici 1975; Tronto and Fisher 1990), care has been encouraging more responsible motives and modes of action.

Nevertheless, despite these positive trends, one cannot fail to recognize that the concept often appears to be still misused to vindicate what Giovanna Borasi and Mirko Zardini (2012) have defined as a 'medicalized' approach to architecture, echoing the hygienic paradigm of nineteenth-century urban planning that paved the way for the technocratic agendas and use of centralized and rationalist Modernist design.

This can be contrasted with concerns for more democratic design methods and processes, where care can be differently identified in some participatory approaches in which the role of the expert is strongly called into question (Awan et al. 2011; Blundell Jones et al. 2005; Dodd 2020). This willingness to include users' voices, wishes, and needs has been further expanded by feminist modes of inquiry in architecture, which have been trying to envision alternative practices to make audible and visible what is excluded by dominant thought and ideologies (Petrescu 2007). Recent feminist insights in science and technology studies (STS) by Isabelle Stengers (2005), Annemarie Mol, Ingunn Moser, Jeannette Pols (2010), and María Puig de la Bellacasa (2017) have gone even further in this direction, calling for the need to remain open to uncertainty, to dig beyond the consensual ways in which a situation is presented, and to remain skeptical toward the tempting relief offered by 'once and for all' solutions. Not only does this approach invite bringing to the fore diverse and often neglected entities, it also allows us to unsettle our own ways of knowing and open up new possibilities for architectural practice.

In this contribution I will focus on a series of experiments within pedagogical spaces of architecture and activist collectives inspired by such perspectives, including an ongoing experience in which I am directly involved, through which I seek to re-learn my own design 
practice from neurodiversity. Care in these experiments becomes an even more radical means to reverse exclusions: Paraphrasing Vinciane Despret (2004: 131), it is a way of learning "to be affected" by other understandings and versions of the world.

\section{Caring with Architectural Interventions?}

Born out of a response to the devastating global epidemic outbreaks in the nineteenth century, the hygienic paradigm approached the city as an ill body to be healed. This paradigm informed Georges-Eugène Haussmann's extensive regularization of Paris—as well as changes at a much smaller scale, such as the home and, notably, bathroom design adaptations (Budds 2020) — and turned city planning into a technocratic instrument for administration of modern life. The space began to be shaped according to functional categories: Distance between buildings, orientation, standard ratios between individuals, and collective spaces were but a few of the normative devices at the core of the modern movement in architecture. Even nowadays many projects seem to adhere to this technocratic vision of design, with their solutionist logics often relying on a distinctively medical rhetoric. Examples range from 'engaging' cities and buildings that force inhabitants to walk or take the stairs to promote healthier lifestyles and treat diseases to the broad field of 'accessibility urbanism' which resorts, often uncritically, to biomedical categorizations that imply standardized solutions. A number of profit-oriented design proposals that respond to the current COVID-19 pandemic, labelled by Kate Wagner (2020) as 'coronagrifts,' are also emblematic, such as plexiglass shields suspended above dining areas and foot-triggered crosswalk buttons that completely ignore the needs of people such as wheelchair users. While recognizing how technological innovation might be crucial to address current social and environmental challenges, it is necessary to remain vigilant against the market-driven, anthropocentric, and extractive logics through which it is often performed. The uniqueness and peculiarity of different users might often be overlooked, along with potentially harmful effects on the environment.

\section{Care as Non-Token Participation and Feminist Modes of Inquiry}

After all, a critical stance toward such technocratic approaches is not a new topic in itself. Work on participatory architecture by Peter Blundell Jones, Jeremy Till, and Doina Petrescu (2005), and further developed by Melanie Dodd (2020), could be seen as more recent significant attempts. Explicitly opposed to mere placatory forms of participation, this work radically puts into question the role of the expert and expert knowledge. Rather than 'problem-solving,' which often abstracts and controls users' lives, Blundell Jones, Till, and Petrescu claim that design should be 'sense-making,' which “is a matter of altering, respecting, acknowledging, and shaping people's lived worlds" (Forester 1985, cited in Blundell Jones et al. 2005: 33).

As opposed to medicalized and technocratic attitudes, care can be identified here as a willingness to reconceptualize design in a more open and process-oriented manner, which could take into account users' voices, wishes, and needs. In the last decades, such emphasis on more collaborative approaches has been clearly informing a significant number of alternative practices, some of which have been collected in interesting research projects such as Spatial Agency (Awan et al. 2011). ${ }^{2}$ Further relevant steps in this direction have been made under the influence of feminist thought in architecture. Feminist theory, in particular, is the domain in which the concept of care made its appearance in the 1970s (Federici 1975) in reaction to 
conditions of rising inequality provoked by exploitative regimes of capitalist production. In contrast to the primacy of productivity and efficiency, it was conceived as a concern to put all forms of life and their maintenance at the center. Despite its far longer history within feminist perspectives on architecture (Hayden 1982), care has recently gained more attention in this field thanks to political theorist Joan Tronto and Berenice Fisher (1990), whose famous definition underlies its ambivalent nature, always shaped by relations of power. Beyond an attention for people commonly seen as vulnerable, its meaning is extended to the whole complex of activities that make life possible and livable. Along these lines a large number of critical spatial practices continue to emerge, with a commitment to detect unbalanced power relations and bring forward more careful arrangements. Recent initiatives and publications, such as the exhibition Critical Care: Architecture for a Broken Planet and related book curated by Angelika Fitz and Elke Krasny (Fitz et al. 2019), the 2019 edition of the festival URBANBATfest in Spain, and the book Urbanismo Feminista by Col-lectiu Punt 6 (2019), draw upon these perspectives. The situated architectural practices that they comprise seek to move against normative, ableist, sexist, and exploitative models of capital market-oriented economies that have led to the current crisis.

\section{Matters of Care in Architecture}

Some other interesting modes of inquiry in architecture have been offered by STS scholars, in particular through actor-network theory and assemblage thinking, who consider the urban as composed by a multiplicity of hybrid and unstable sociotechnical networks (Farías and Bender 2009). Great focus is being put on a commitment to reassemble urban coexistence informed by the project of 'technical democracy' (Callon et al. 2011), which seeks to debunk the boundaries of what is considered legitimate expert knowledge so as to reverse the effects of technocracy.

Without the aim of providing a complete account of the multiple ways in which STS and design disciplines have been encountering each other in recent years (Varga 2018; Yaneva 2009; Yaneva and Zaera-Polo 2015), I will focus here upon the influence exerted on some experimental design spaces by recent feminist insights in STS such as Stengers' (2005) 'cosmopolitics,' Mol et al.s (2010) 'care in practice,' and Puig de la Bellacasa's (2017) notion of 'matters of care.' Care is intended here as a speculative practice, where speculation, in the authors' perspective, stands for a continuous commitment to inquiry into the multiple, morethan-human ontologies of the world. Rather than a clear path toward a solution, care is thought of "as a domain of problematizations," which, in Foucauldian terms, implies a questioning of accepted 'truths' and probes different versions of the world (Sánchez Criado 2019). Since the 'cosmos,' as Stengers (2005) puts it, cannot be seen as a given shared ground, nor human nature as homogeneous and universal, such perspectives invite us to remain speculative "by not letting a situation or a position - or even the acute awareness of pervasive dominations-define in advance what is or could be" (Puig de la Bellacasa 2017: 60). Radicalizing the inclusivist commitment attributed to care, they not only call for 'visibilizing' neglected entities, but for learning how to be affected by them and engaging inventively into the exploration of unknown prospects of alternative futures. Speculation is here, quoting Didier Debaise and Stengers (2017: 14), "a way of giving rise to possibles." Tender Infrastructures, the design studios developed between 2010 and 2013 by Nerea Calvillo and Miguel Mesa del Castillo (2018) at the University of Architecture of Alicante, moved exactly along these lines. In this sense, their 
idea of substituting the notion of building with the one of 'infrastructural ecosystems,' so as to highlight the complex socio-material ecology of urban space, appears relevant. This way, the condition of 'users' of an architecture is extended to certain ecosystems, endangered species, or marginalized communities. The idea, in short, was to consider infrastructures as 'matters of care' and design as a careful intervention aimed at detecting and giving visibility to entities that risked being left out by knowledge production practices. The first phase of the working plan involved the visualization of relationships, conflicts, and distributions of power among the actants of the socio-material ecosystem, with special attention to neglected entities. As a final task, students were asked to intervene through the installation of architectural prosthesis in order to redistribute agencies. One of the final proposals, for a project revolving around the Thermomix, was a speculative machine meant to unveil different agencies and re-compose the relationships between the market, the users, domestic spaces, and health food. The aim of the experiment was, in Puig de la Bellacasa's (2011: 94) words, "not only to expose or reveal invisible labors of care, but also to generate care."

Between 2015 and 2017, the STS-informed anthropologists Ignacio Farías and Tomás Sánchez Criado (2018) held three studio project courses under the title 'Design in Crisis' at the Department of Architecture of the Technical University of Munich. Their experiments, revolving around particular more-than-human challenges, were aimed at exploring the meaning and prospects of 'technical democracy' for the education of future architects.

In contrast to the idea of Callon, Lascoumes, and Barthe (2011), Farías and Sánchez Criado (2018: 236, original emphasis) signaled "the need to move from the "expertization of laypersons' $[. .$.$] to a 're-sensitization of experts'" and promoted 'technical democracy' through chal-$ lenging classroom briefs and situations. The aim was in fact to undermine hegemonic forms of expertise and, interestingly, to "explicitly block or undo the particular 'responsiveness' of architectural modes of reasoning" proper to a 'humanitarian' approach to design practice (Sánchez Criado 2021: 67, original emphasis). To this end, they drew inspiration from Jacques Rancière's (1987) The Ignorant Schoolmaster, whose radical-democratic principle consisted of eliciting students' intelligence and avoiding asymmetrical relations between them and the teachers. Rather than conventional teaching methods relying on discursive concepts and readings, they used a more experiential mode, following Tim Ingold's (2013: 1) invitation to know 'from the inside,' that is: understanding architecture through an engaged exploration of its methods and practices. Their aim was in fact to develop architectural 'intraventions,' a term coined by Alberto Altés (2016) to address his pedagogical experiments as speculative design experiences aimed at understanding the relations between things, materials, and people. Drawing inspiration from Sánchez Criado's (2021: 61) experience with accessibility activists, the course 'Design in Crisis 2: Coming to Our Senses,' sought "to treat blindness as a method" to radically challenge the exclusionary effects of ocular-centric practices and techniques of architectural design. In the first phase of the course some sensory explorations were carried out to explore multisensory understandings of space and "learn not to see" (ibid.: 62). Among these there were blindfolded walks, after which students were required to represent their path in non-euclidian ways; and collective records of the smells of a street, that were later transposed into three-dimensional models. Interestingly, the final assigned task was not to design something "for the blind" (ibid.: 63) but to learn from them in order to prototype a toolkit for practicing architecture multi-sensorially, hence, to be sensitized to what experiencing space as diverse kinds of bodies might mean. Great emphasis was also put on the documentation of the whole process to allow students to take moments of self-reflexivity 
on the different issues they encountered and the choices they made. The toolkit itself, whose final version was named ManualCad, was not in fact meant to provide a solution, but rather to function as a re-learning device to encourage awareness of different, potentially excluded forms of knowledge.

Sánchez Criado, in his ethnographic account of the work of the activist collective En Torno a la Silla (ETS), of which he himself was a member, had already stressed this speculative nuance of care by showing how design might become a form of "joint problem-making" (Sánchez Criado and Rodríguez Giralt 2016: 201). Whereas market care technologies, such as technical aids, commonly embody the designer's expertise without paying attention to the user's real and individual needs, this approach portrays care as a more radical way of sharing problems and knowledge between users and designers to collaboratively explore possible solutions. Hosted by Medialab-Prado Madrid's Funcionamientos workshops (2012-2013), revolving around the idea of rethinking accessibility in urban space and technical aids through open design practice, ETS engaged in a collective exploration aimed at designing three objects for one of its members who was in need of a new wheelchair: an armrest/briefcase, a folding table, and a portable ramp. This was meant to compose a freely licensed kit that might favor both the user (seen neither as an individual who needed to be included, nor as an object) and his friends. The idea was to enable new alliances through collective material explorations aimed at hacking and rearranging social and technical scripts, where the architect might really join "a political space" (Sánchez Criado and Rodríguez Giralt 2016: 211), rather than being the only one managing the process. Care was explored here 'in practice,' as a matter of collective tinkering and "attentive experimentation" (Mol et al. 2010: 13).

\section{Re-Learning Architecture from Neurodiversity}

My interest in these experiences motivated me to get in touch with Farías and Sánchez Criado and undertake a research visit at the Stadtlabor for Multimodal Anthropology, a research platform at the Institute for European Ethnology of Humboldt-Universität zu Berlin. In particular, since late 2019, Sánchez Criado and I engaged in developing an auto-pedagogical situation-again in line with Rancière's (1987) approach—where we both could speculate on what the conceptual repertoire of care and anthropological practice might offer to rethink and transform architectural design. A series of contingencies, such as Sánchez Criado's long experience with issues related to functional diversity and urban accessibility activism, and the interest and willingness to collaborate showed by my flatmate and her son, Moritz, a 'neurodiverse' person, motivated us to undertake an experiment to explore what neurodiversity ${ }^{3}$ could teach architecture. Since this experience needs further systematization, in this contribution I will only dwell on an incomplete account of the openings that it has been offering me.

Initial research on existing devices and methods (see Figure 14.1) allowed us to reflect on the problem-solving approach through which accessibility urbanism is usually addressed, mostly revealing architects' uncritical inclination to use biomedical categories.

Design codes, ranging from all-controlling standards to simple sets of "guidelines that outline key principles of good design" (Imrie and Street 2011: 246), are built on ocularcentric and volumetric understanding of space, whereas neurodiverse people would rather need more complex and multisensory approaches. Furthermore, accessibility guidelines such as the Principles of Universal Design (Center for Universal Design 1997), ${ }^{4}$ despite being loose in their nature, "often reproduce the appearance of a stable, coherent phenomenon," (Hamraie 


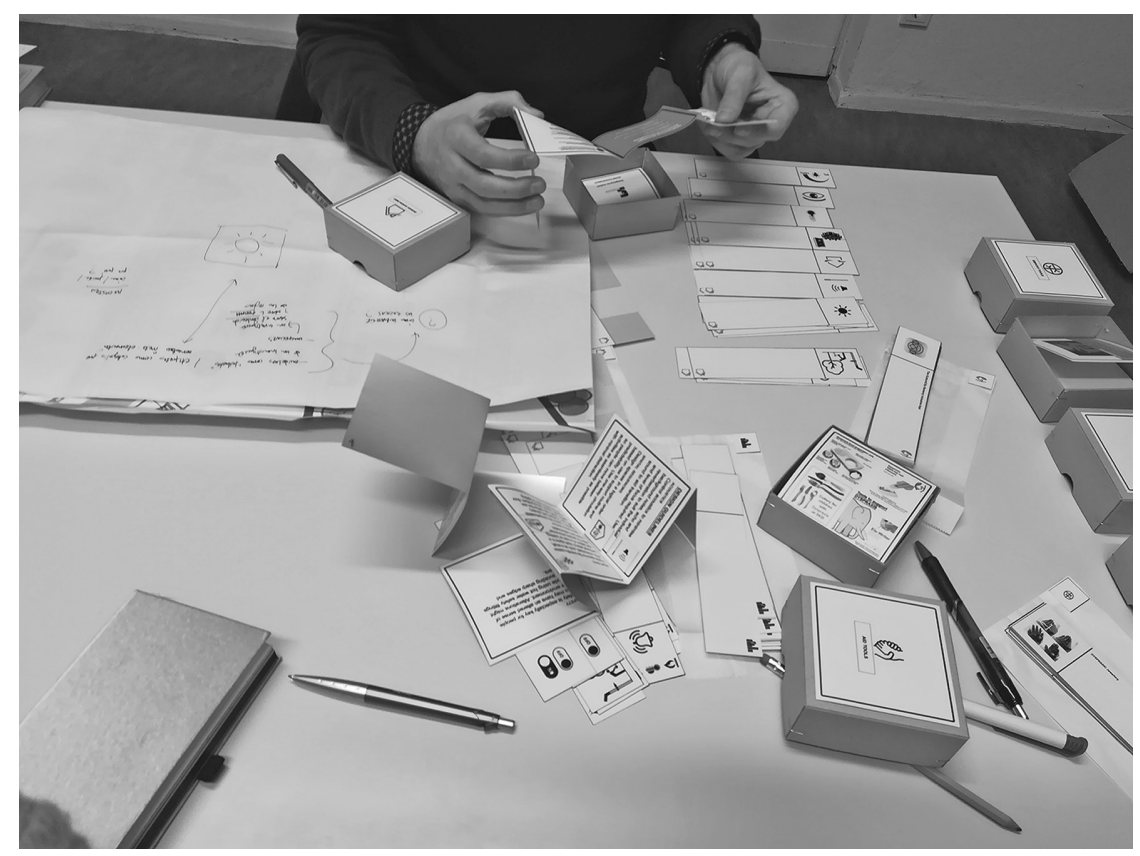

FIGURE 14.1 Research on existing methods and tools. Source: Micol Rispoli, 2020.

2017: 227) preventing the access to the series of frictions and revisions through which they have been outlined. Other steps included sensory explorations - such as backward walks in public and movements 'against music'5 - to navigate the multisensory terrains which could allow me to compromise my modes of design and learn other ways of experiencing space; an ethnographic walk through a Berlin neighborhood with Patrick Bieler, PhD candidate at the Institute for European Ethnology of Humboldt-Universität zu Berlin, whose research investigates on how people with mental distress relate to social and material urban environments in everyday life; spending a lot of time with Moritz and exploring with his mother and brothers every corner of the house where he lived as a child (see Figure 14.2), to tentatively learn his way of seeing, feeling, and walking through space.

Moritz was in no way treated as an object of research or experiment, nor did I aim to give him assistance by means of my professional expertise. On the contrary, my relationship with him, a subject who goes beyond the traditional figure of 'the client' in architecture, soon revealed how limiting and mostly ineffective the knowledge, skills, and tools that I was initially counting on were and allowed me to learn other ways of thinking and experiencing space. I tried to understand and learn the way in which he sees, where the contrast between different colors is more blurred and the angle of view is narrower than mine; the way in which he hears, where the contrast between different sounds also appears to be less pronounced than mine; the way in which he touches, where the medically labelled 'lack of fine motor skills' renders his hand contact different from mine. To this end, I carried out a number of material explorations to prototype new, alternative devices which differ from the ones offered by traditional architecture's visual culture (Henderson 1999) and let me explore space in new ways. These sketchy attempts included binocular lenses that channel sight and reduce contrast (see 


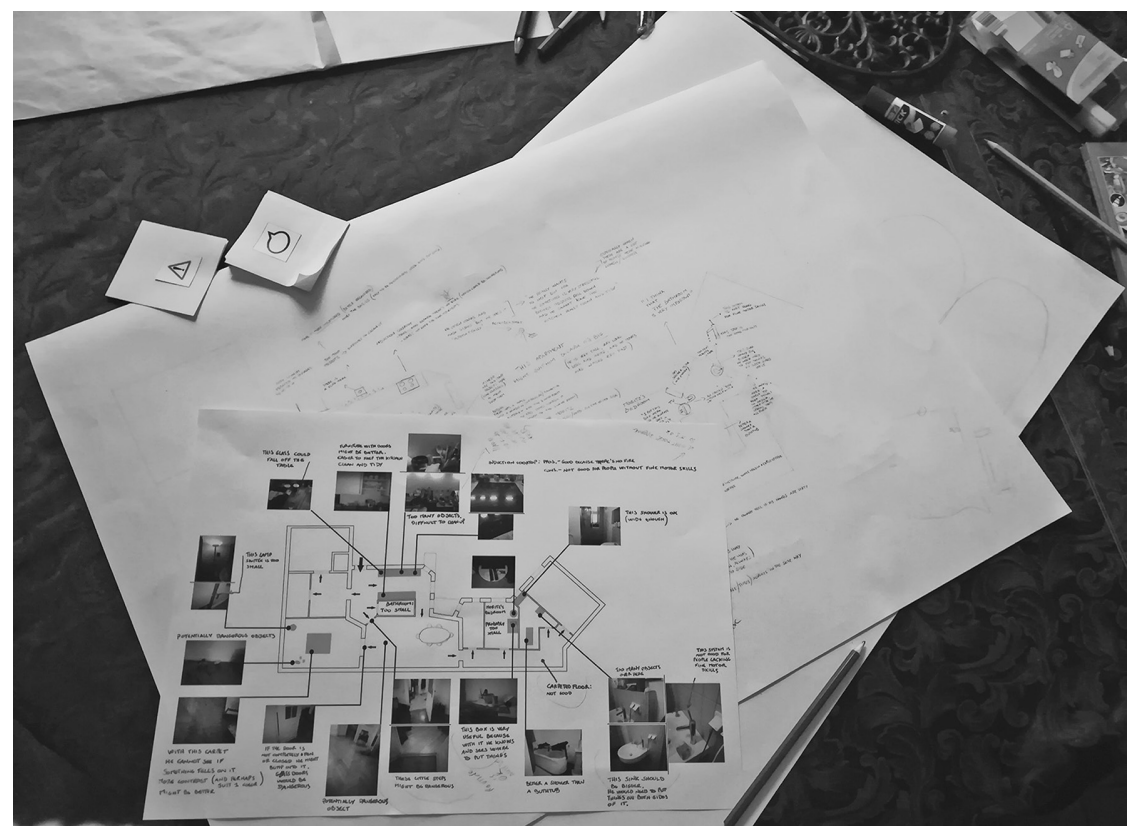

FIGURE 14.2 House exploration. Source: Micol Rispoli, 2020.

Figure 14.3), sound recordings-later merged together and adjusted to blur contrast between different sounds - and worker gloves to experience other ways of touching and handling things.

I had the chance to learn that, beyond volumetric understanding, stabilized by a visual culture of design, space is an atmosphere (McCormack 2018), an interweaving of complex sociomaterial relations; that other forms of knowledge, if asked the right questions, as Despret (2016) would say, can offer us crucial help; that a new type of contract might be needed to manage the relationship between the architect and the client. One that, against the technocratic pact of social utility of design, does not end up with providing a service and abandoning the object of design once realized, but rather, that transforms this relationship into an engaged and lasting collaboration aimed at carefully questioning and rearranging tentative solutions over time.

In particular, by constantly raising questions and inviting me to produce records of all the progressive outcomes of this experience, Sánchez Criado prompted me to develop an ethnographic attentiveness toward my gestures and the knowledge-making and world-building effects of instruments and methods I was using. The aim was again to design a toolkit conceived as a re-learning device, which would both provide a complete account and technical summary of our process, and eventually allow other architects to experimentally follow, and even change, our steps. In ironic opposition to Ernst Neufert's (1936) Bauentwurfslehre, which might be translated as 'building design education' and reflects an all-encompassing logic, this toolkit will probably be entitled Re-thinking design, thus invoking careful explorations in search of alternative possibilities for architecture. What happens to architectural design if, besides ensuring that it includes a variety of human and non-human actors who are usually not taken into account, we open it up to experimental re-learnings from them? 


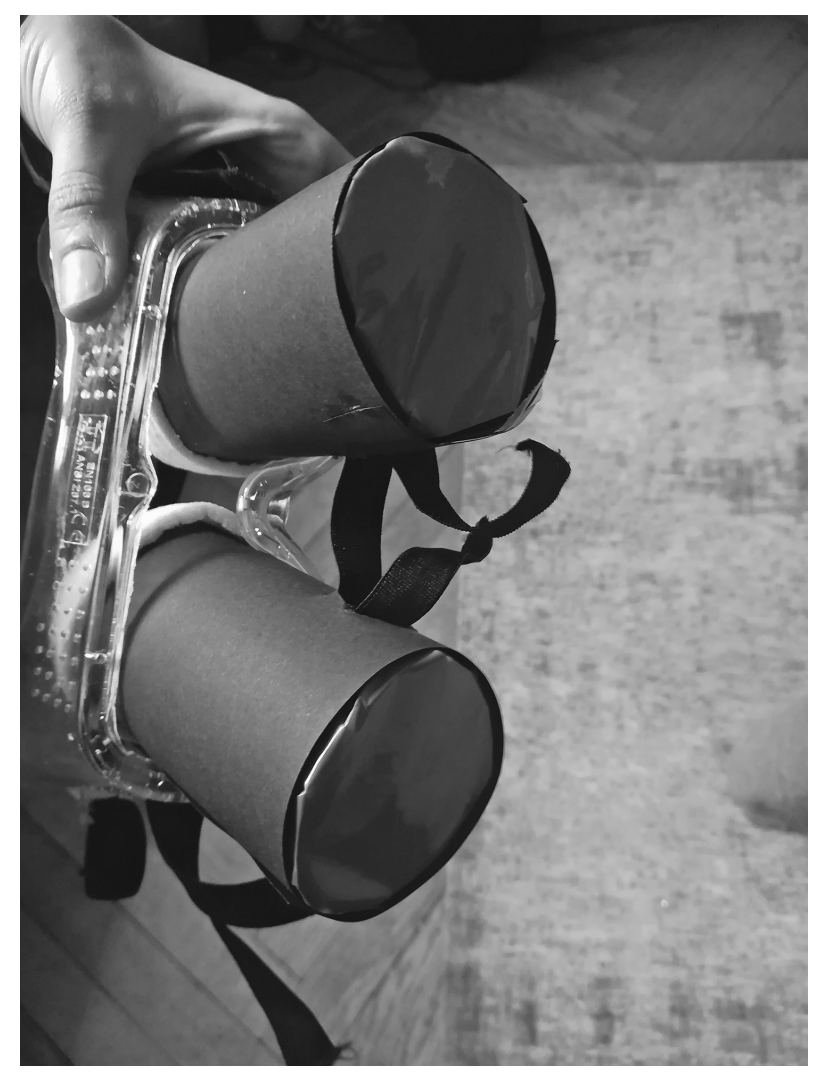

FIGURE 14.3 Prototype of binocular lenses. Source: Micol Rispoli, 2020.

Care is taken here as willingness to take on risks and learn to be affected, moved, touched by what matters for other beings (Despret 2004). Against the encyclopedic approach of Neufert's handbook, our Re-thinking design is intended to be a sort of open cookbook, meant to collect countless experiments. Stable guidelines become open recipes, and their abstract nature will be replaced and enriched by progressive findings and rearrangements, brought forward by different experiments. Once again, the focus on documenting the whole experience of crisis, thus including doubts, failures, and different attempts to deal with the issues encountered, is set on the conviction that what care brings to design goes beyond a moral imperative to provide inherently good and definitive solutions. Conceived as the ability to be exposed to the unknown, it rather transforms design in a speculative process, through which one can recursively reflect on and unsettle the potentially harmful ways in which architects have been trained and are used to practicing their profession.

\section{Conclusions}

In this contribution I analyzed different motives and modes of action which the notion of care has been suggesting to designers. In the first part I touched upon some current trends that still remind me of a hygienic and medicalized understanding of design, in line with 
nineteenth century and Modernist modes of planning. Such an approach portrays care as an imperative to uncritically offer expert and technologically innovative solutions to the present crisis, often overlooking their counter effects. On the other hand, care, as a concern around more inclusive modes of designing, is brought forward by some participatory approaches to architecture, further strengthened by the influence of feminist ethics and its efforts in unveiling imbalanced power relations and excluded entities.

Finally, care is explored in its even more radically transformative potential by design experiences resorting to some recent feminist insights in STS, as a way to 'activate the possible.' Some pedagogical programs have been experimentally creating situations which might provoke a crisis of conventional methods and means of design, forcing students to speculate on different possibilities. Along the same lines, for the ETS collective care was a form of 'joint problem-making,' aimed at turning design practice into a political space where existing material arrangements are collectively questioned to produce alternative versions. In the joint auto-pedagogical project I conducted with Sánchez Criado, care has been conceived as a conceptual and practical repertoire to experimentally re-learn architectural practice from the experiential knowledge of neurodiverse people, who require me to generate alternative material arrangements. Starting from the assumption that design practice, whether through methods, tools, or representations, constitutes a particular form of knowledge which both reflects and shapes the world, such a perspective implies an epistemological shift which forces us to question and revise the structures of knowledge production itself. Not only this notion of care calls for a different way of practicing architecture in terms of spatial interventions but affects the very logic of design itself. Rather than a service relation, meant to provide finalized solutions, a careful design practice here implies a never stabilized process of investigating the unknown. It is a way, as Donna Haraway (2016:1) would say, of "staying with the trouble."

Openly embracing the complexity of our times and beyond "clear-cut knowledge of what needs to be done and how" (Sánchez Criado 2019), care here is intended as a domain of problematizations requiring us to slow down, debunk consensual narratives, learn to be affected and open up unforeseen forms of world-making.

\section{Notes}

1 E.g. Broken Nature at the 2019 Milano Triennale; Critical Care:Architecture and Urbanism for a Broken Planet at the Architekturzentrum Wien (Fitz et al. 2019); Floating University by Raumlabor (whose 2019 theme was 'Climate Care'); URBANBATfest19.

2 The term 'spatial agency' was also used by the research group AGENCY (see Kossak et al. 2009).

3 The term 'neurodiversity' was coined as a reaction to the medical model of disability, which considers the body a machine to be normatively 'fixed' (Singer 1999). Its antecedents can be found in the antipsychiatry movement and its intellectual vanguard, e.g. Foucault 1965.

4 The term 'universal design' was coined by Mace 1985. The 'principles' were released by the Center for Universal Design at North Carolina State University in Raleigh (1997).

5 The experiments have been taken from Coates 2014.

\section{References}

Altés, A. (2016) Performance, Responsibility, Curiosity and Care: Choreographing Architectural Values. In A. Altés, A. Jara and L. Correia (eds.) The Power of Experiment. Lisbon: Artéria-Humanizing Architecture, pp. 104-139. 
Awan, N., Schneider, T. and Till, J. (2011) Spatial Agency: Other Ways of Doing Architecture. New York: Routledge.

Blundell Jones, P., Petrescu, D. and Till,J. (eds.) (2005) Architecture and Participation. New York: Spon Press.

Borasi, G. and Zardini, M. (eds.) (2012) Imperfect Health: The Medicalization of Architecture. Baden: Lars Müller Publishers.

Budds, D. (2020, 17 March) Design in the Age of Pandemics. Curbed [Online]. Available at https://ww w.curbed.com/2020/3/17/21178962/design-pandemics-coronavirus-quarantine [Accessed 10 June 2020].

Callon, M., Lascoumes, P. and Barthe, Y. (2011) Acting in an Uncertain World: An Essay on Technical Democracy. Cambridge, MA: MIT Press.

Calvillo, N. and Mesa del Castillo, M. (2018) Tender Infrastructures: Designing with Care, or Contributions to 'Matters of Care' in Architecture. Diseña 12: 172-195.

Center for Universal Design (1997) The Principles of Universal Design [Online]. Raleigh: North Carolina State University. Available at https://projects.ncsu.edu/ncsu/design/cud/pubs_p/docs/poster.pdf [Accessed 2 October 2020].

Coates, M. (2014) A Practical Guide to Unconscious Reasoning. London: Book Works.

Col-lectiu Punt 6 (2019) Urbanismo Feminista: Por una Transformación Radical de los Espacios de Vida. Barcelona: Virus Editorial.

Debaise, D. and Stengers, I. (2017) The Insistence of Possibles: Towards a Speculative Pragmatism. Parse 7: 13-19.

Despret,V. (2004) The Body We Care For: Figures of Anthropo-Zoo-Genesis. Body and Society 10(2-3): $111-134$.

Despret,V. (2016) What Would Animals Say If We Asked the Right Questions? Minneapolis: University of Minnesota Press.

Dodd, M. (ed.) (2020) Spatial Practices: Modes of Action and Engagement with the City. New York: Routledge.

Farías, I. and Bender,T. (eds.) (2009) Urban Assemblages: How Actor-Network Theory Changes Urban Studies. New York: Routledge.

Farías, I. and Sánchez Criado, T. (2018) Co-Laborations, Entrapments, Intraventions: Pedagogical Approaches to Technical Democracy in Architectural Design. Diseña 12: 228-255.

Federici, S. (1975) Wages Against Housework. Bristol: Power of Women Collective and Falling Wall Press.

Fitz, A., Krasny, E. and Architekturzentrum Wien (eds.) (2019) Critical Care:Architecture and Urbanism for a Broken Planet. Cambridge, MA: MIT Press.

Forester, J. (1985) Designing: Making Sense Together in Practical Conversations. Journal of Architectural Education 38(3): 14-20.

Foucault, M. (1965) Madness and Civilization: A History of Insanity in the Age of Reason. New York: Random House.

Hamraie, A. (2017) Building Access: Universal Design and the Politics of Disability. Minneapolis: University of Minnesota Press.

Haraway, D.J. (2016) Staying with the Trouble: Making Kin in the Chthulucene. Durham: Duke University Press.

Hayden, D. (1982) The Grand Domestic Revolution: A History of Feminist Designs for American Homes, Neighborhoods, and Cities. Cambridge, MA: MIT Press.

Henderson, K. (1999) On Line and On Paper:Visual Representations, Visual Culture, and Computer Graphics in Design Engineering. Cambridge, MA: MIT Press.

Imrie, R. and Street, E. (2011) Architectural Design and Regulation. Oxford:Wiley-Blackwell.

Ingold, T. (2013) Making: Anthropology, Archaeology, Art and Architecture. New York: Routledge.

Kossak, F., Petrescu, D., Schneider, T., Tyszczuk, R. and Walker, S. (eds.) (2009) Agency: Working with Uncertain Architectures. New York: Routledge.

Mace, R. (1985) Universal Design: Barrier Free Environments for Everyone. Designers West 33(1): 147-152.

McCormack, D.P. (2018) Atmospheric Things: On the Allure of Elemental Envelopment. Durham: Duke University Press. 
Mol, A., Moser, I. and Pols, J. (eds.) (2010) Care in Practice: On Tinkering in Clinics, Homes and Farms. Bielefeld:Transcript.

Neufert, E. (1936) Bauentwurfslehre. Berlin: Bauwelt.

Petrescu, D. (ed.) (2007) Altering Practices: Feminist Politics and Poetics of Space. New York: Routledge.

Puig de la Bellacasa, M. (2011) Matters of Care in Technoscience: Assembling Neglected Things. Social Studies of Science 41(1): 85-106.

Puig de la Bellacasa, M. (2017) Matters of Care: Speculative Ethics in More than Human Worlds. Minneapolis: University of Minnesota Press.

Rancière, J. (1987) Le Maître Ignorant: Cinq Leçons sur l'Émancipation Intellectuelle. Paris: Fayard.

Sánchez Criado, T. (2019) How to Care? [Online]. Keynote speech for the 8th Nordic Design Research Society Conference, Aalto University, Helsinki, 3 June. Available at https://tscriado.org/2019/01/27/ nordes2019-whocares/ [Accessed 10 June 2020].

Sánchez Criado,T. (2021) Anthropology as a Careful Design Practice? Zeitschrift für Ethnologie 145(2020, 1): 47-70.

Sánchez Criado, T. and Rodríguez Giralt, I. (2016) Caring Through Design? En Torno a la Silla and the 'Joint Problem-Making' of Technical Aids. In C. Bates, R. Imrie and K. Kullman (eds.) Care and Design: Bodies, Buildings, Cities. Oxford: Wiley-Blackwell, pp. 198-218.

Singer, J. (1999) 'Why Can't You Be Normal for Once in Your Life?' From a 'Problem with No Name' to the Emergence of a New Category of Difference. In M. Corker and S. French (eds.) Disability Discourse. Buckingham: Open University Press, pp. 59-67.

Stengers, I. (2005) A Cosmopolitical Proposal. In: B. Latour and P. Weibel (eds.) Making Things Public: Atmospheres of Democracy. Cambridge, MA: MIT Press, pp. 994-1003.

Tronto, J.C. and Fisher, B. (1990) Toward a Feminist Theory of Caring. In E.K. Abel and M.K. Nelson (eds.) Circles of Care: Work and Identity in Women's Lives. Albany: State University of New York Press, pp. 36-54.

Varga, H.M. (2018) On Design and Making with STS. Diseña 12: 30-51.

Wagner, K. (2020, 23 May) Coronagrifting: A Design Phenomenon. McMansion Hell [Online]. Available at https://mcmansionhell.com/post/618938984050147328/coronagrifting-a-design-phenom enon?fbclid=IwAR0H-vyPIdQqrQx8VPT1vjVv11EBWKGJQkrFvf4q7UUOWhqkLwhrijGijj0 [Accessed 10 June 2020].

Yaneva, A. (2009) Made by the Office for Metropolitan Architecture: An Ethnography of Design. Rotterdam: NAi Uitgevers.

Yaneva, A. and Zaera-Polo, A. (eds.) (2015) What Is Cosmopolitical Design? Design, Nature and the Built Environment. New York: Routledge. 